\title{
The Analysis of Declaration of Illocutionary Acts of the Korean-English Drama "I Hear Your Voice"
}

\author{
Endang Sartika, Sari Marzuqoh, Khoirul Majid
}

IAIN Purwokerto

E-mail:Endangsartika.ens@gmail.com

\begin{tabular}{ll}
\hline & ABSTRACT \\
Submission & This study deals with the types of declaration of illocutionary acts in the \\
Track: & Korean-English Drama "I Hear Your Voice". The objectives of this study \\
Received: & are (1) to find and classify the utterances in the English subtitle of the \\
$01-01-2019$ & Korean drama entitled "I Hear Your Voice" that belongs to declaration \\
Final Revision: & of illocutionary acts, (2) to analyze the implication of the declaration of \\
$20-03-2019$ & illocutionary act found in the Korean English drama "I Hear Your \\
Available online: & Voice". This research applies descriptive qualitative method. The objects \\
$27-03-2019$ & of this study are English Subtitles of the drama in episode 8 to 13 which \\
Corresponding & is containing the utterances of Declaration of Illocutionary Acts. The \\
Author: & researcher found 40 declaration of illocutionary act utterance which is \\
Endang Sartika & divided into five types of Declaration of Illocutionary acts and the \\
E-mail: & dominant types was Sentencing. For specific result, the researcher \\
endangsartika.ens@gmail.com & provided the percentage in detail; Resigning (5\%) in 2 data, Demising \\
& (12,5\%) in 5 data, Naming (17,5\%) in 7 data, Appointing (20\%) in 8 data, \\
& and Sentencing (45\%) in 12 data. The implication of the result of this \\
& research toward English Language Teaching is that this research could \\
be authentic material by teachers or lecturers to teach Pragmatic & especially about Speech Acts.
\end{tabular}

Key words: Declaration, Illocutionary acts, Speech acts.

\section{INTRODUCTION}

Language is the most important thing in the society. Language enables people to communicate, cooperate and get along each other. Language is a system used by the people to gain information. Through the language, the humans are able to communicate properly. The language makes the interaction happened. However, common people make interaction and communication unstructured, but still the most important is that their speech can be understood and accepted by others. George Yule (1996:47) also said that in the effort to express and asserting himself, people are not only produce grammatical structure sentences, but they also produce or show actions in 
that language. Therefore, there is always a meaning behind the speech utter by people. It is called speech act.

Speech act is an action which is used to make such as; requesting, informing, commanding and questioning (Cahyono, 1994:224). According to Austin, the sentences are not only utilized to utter something, to give direction to other, but also are utilized to do something actively (Cahyono, 1995:223). The sentences cannot be used to respond true or false statement. Sentence and utterance stated by Austin are called performatives.

Moreover, Austin in Levinson (1983:236) cited by Cahyono (1995:224) classified speech act to be three parts and the parts are implemented at the same time. First, locutionary act is a locution a word or sentence based on meaning and the reference, sometimes is called speaker's utterance. Second, illocutionary act is a statement, offering, promise, and other utterance or performative expression directly, sometimes is called speaker's intention. On the basis Searle's categories of illocution act, Searle defined to some parts. Third, perlocutionary act is an affect that is produces by hearer because utterance sentence and reaction from that, or sometimes is called hearer's reaction. The effect such as; persuade, deceive encourage, irritate, frighten, amuse, inspire, impress, distract, relieve tension, embarrass, attract attention and bore.

Based on Searle there are five categories of illocutionary act they are; representative, directive, commisive, expressive, and declaration. Declarative is a speech act that changes the reality in accord with the proposition of the declaration. Representatives are the types of speech acts that commit the speaker in believing something to be truth. Directives are the expressions in order to direct the hearer to do something such as; suggesting, commanding, or order something. Commissives are the expressions used by the speakers to commit themselves to do some future actions such as; promising, threatening, refusing, and pledging. And the last is declarative which is speech act used to announce something clearly and have direct change to the world through certain utterances (Yule, 1996:53-54).

According to Leech (1983: 105), declarations are illocutionary whose successful performances bring about the correspondence between the propositional content and reality e.g. 
resigning, demising, christening, naming, excommunicating, appointing, sentencing, etc. Yule (1996:53) inserted that this kind of speech acts can change the world via utterance.

Example: $\quad$ Priest: I pronounce you husband and wife

Referee: you're out!

Jury foreman: we find the defendant guilty

In using a declaration the speaker changes the world via word. This kind of speech act is very special and used in very special circumstances which the expression used to change the world via utterances. This kind of speech acts are really rarely to be used, because only by a certain institutional role and in a specific context. The table below gives a brief understanding about the relationship between speech act types and language functions, which was following Searle's though (Yule 1996:53-55)

\section{Table 1 The General Function of Speech Act According to Searle}

\begin{tabular}{|l|l|l|}
\hline Speech act type & Direction of fit & $\begin{array}{l}\text { S= speaker } \\
\text { X= situation }\end{array}$ \\
\hline Representative & Make words fit the world & S believe $x$ \\
\hline Directive & Make the world fit the world & S wants $x$ \\
\hline Commisive & Make the world fit the words & S intend $x$ \\
\hline Cxpressive & Make the words fit the world & S feels $x$ \\
\hline Declaration & World change the world & S cause $x$ \\
\hline
\end{tabular}

George Yule. 1996. Pragmatics. P 54-55

Based on the above explanation, the researcher interested to find and analyze the declaration illocutionary acts on fiction literature to give more understanding about illocutionary act. The researcher chooses the Korean-English drama entitled "I Hear Your Voice" to analyze the declaration of illocutionary acts found on the conversation in this drama. The researcher chooses the English subtitle of Korean drama "I Hear Your Voice", because the themes in this drama are about crime, judges, and law. There are many utterances including the declaration of illocutionary acts. The researcher would like to present the reason chooses this drama as the object of the study. According to Searle cited by Leech (1991:105-106), stated that declaration illocutionary act is

"A very special category of speech acts; they are performed, normally speaking, by someone who is especially authorized to do so within some institutional framework (classical examples are judges sentencing offenders, ministers of religion christening 
babies, dignitaries naming ships, etc). The person who makes a declaration uses language as an outward sign that some institution (social, religious, legal, etc) action is performed".

Considering, Searle's statement above, the researcher interesting in conducting this research which focuses on a very special category of speech act, which is only can be performed by a special person in a special circumstances. I Hear Your Voice is a Korean drama which is told about the crimes, judgments, and court. The actors in this drama also act as lawyers, prosecutors, judges and police which people who have special authorized to do so within some institutional frameworks and make a declaration uses language as an outward sign that some institution actions were performed. Therefore the researcher interested in conducting analysis in the research entitled "THE ANALYSIS OF DECLARATION OF ILLOCUTIONARY ACTS IN THE KOREANENGLISH DRAMA “I HEAR YOUR VOICE”.

\section{RESEARCH METHODOLOGY}

In this research, the researcher used descriptive qualitative research method. Qualitative research method is defined as a research procedure which produces descriptive data in the form of words written or spoken of the person (Bogdan and Taylor 1975:5 in Moleong 2002:3). According to Arikunto (2010:3) descriptive research is the study intended to investigate the situation, condition, circumstances, events, and other activities, and the result presented in the form of the research report.

The objects of this research was the English subtitled on the Korean drama entitled "I Hear Your Voice", which limited on utterances in the English subtitle on the Korean drama entitled "I Hear Your Voice" including the declaration of illocutionary acts. The researcher took six episodes

of eight teen episodes of the drama that are from $8^{\text {th }}$ to $13^{\text {th }}$ episode. The researcher took those episodes because on those episodes focused on one case that was indicated there were many declaration utterances. This research was held in November $13^{\text {th }}$ to December $5^{\text {th }}, 2013$.

In this research the primary data source was taken from utterances found in the English subtitle on the video of the Korean drama entitled "I Hear Your Voice". The data focused on the declaration of illocutionary acts. The video of this drama was downloaded from dramacrazy.eu in the internet. This drama was using Korean with running English subtitle. The running English 
subtitle from this drama was the primary data in this research. The primary data was taken by transcribing the running English subtitle from the video which was downloaded from dramacrazy.eu, which was the web made especially for the Korean drama lovers around the world. In addition, the researcher used English drama script of "I Hear Your Voice" as secondary data to support the primary data.

The data are collected through some steps, they are observation, transcribing and documentation. The researcher did observation by watching the videos of the Korean drama entitled "I Hear Your Voice" to help find and select the declaration of illocutionary utterances. This method was used to help the researcher conduct this research as the supporting materials and data because the drama script that the researcher had was not complete. As a result, the researcher decided to support this research by doing observation to find the declaration utterances in this drama. The observation that the researcher did was watching the movie. After doing observation by watching the videos of drama I Hear Your Voice, the researcher transcribed the English subtitles of this drama. This activity was done to help the researcher conducting the written data as the primary data of this research. Transcription is process to encompass the talk, time, nonverbal actions, speaker and the hearer, the researcher transcribed the English subtitle from the Korean drama by determining the speaker, the hearer and the time. The writer typed the transcription in the table form consist of episode, time, name of the speaker and the dialogue. The researcher also held documentation by underline and highlight the utterances found in the transcription to find the variables that have been defined that is declaration utterances. If there is appears declaration utterances the researcher highlight or underline those utterances.

The data were analyzed by selecting and categorizing the utterance of declaration of illocutionary act found in the Korean drama "I Hear Your Voice". The researcher selected the utterance in the Korean-English drama entitled "I Hear Your Voice" that includes declaration illocutionary acts. The researcher leaved out the other utterances. The researcher classified the utterance based on the forms of declaration of illocutionary act whether resigning, demising, christening, naming, excommunicating, appointing, sentencing, declaring war, and firing from employment. 


\section{DISCUSSION}

The researcher analyzed the utterances in this drama which were performed by those people who have authorization to declare something which can change the world via their utterances. The judges, lawyers, prosecutions and police are people who have that authorization to do so, they can declare someone guilty or innocent, and declare someone became the suspect of the crime or witness. In this drama the researcher found many declaration utterances which were uttered by those institutional people such as sentencing, appointing, resigning, naming, and demising.

\section{Type of Declaration Illocutionary Act}

In the drama I Hear Your Voice, the researcher found many kinds of declaration utterances presented as well in the table below:

Table 2 Type of Declaration of Illocutionary Act

\begin{tabular}{|c|l|c|c|}
\hline No & Type of Declaration & Number & Percentage \\
\hline 1. & Resigning & 2 & $4,8 \%$ \\
\hline 2. & Demising & 3 & $7,3 \%$ \\
\hline 3. & Naming & 7 & $17,01 \%$ \\
\hline 4. & Appointing & 10 & $24,4 \%$ \\
\hline 5. & Sentencing & 19 & $46,3 \%$ \\
\hline \multicolumn{2}{r|}{ Total } & 41 & $100 \%$ \\
\hline
\end{tabular}

The above table was presented the result of the data. It could be seen that there are 38 utterances of declaration of illocutionary act which divided into five categories. It was consist of 2 utterances of resigning, 3 utterances of demising, 7 utterances of naming, 8 utterances of appointing and the highest nominal of the declaration of illocutionary act was sentencing which was consist of 18 utterances.

\section{Resigning}

Resigning is expression used to declare someone resigns from their job. In this research the researcher found 2 utterances that belong to the types of declaration of illocutionary acts that is resigning. The researcher found in $9^{\text {th }}$ and $14^{\text {th }}$ episode of the drama. 
Table 3 Resigning Declaration

\begin{tabular}{|c|c|c|l|}
\hline No. & Episode & Time & \multicolumn{1}{c|}{ Utterance } \\
\hline 1. & 9 & $00: 38: 07$ & $\begin{array}{l}\text { Lawyer Jang: "Attorney Cha gave up his position as a public } \\
\text { defender." }\end{array}$ \\
\hline 2. & 14 & $00: 12: 19$ & $\begin{array}{l}\text { Lawyer Uhm: "I can never be a lawyer in this circumstance. } \\
\text { I can't" }\end{array}$ \\
\hline Total: & \multicolumn{3}{|c}{$\mathbf{2}$} \\
\hline
\end{tabular}

\section{Demising}

Demising is expression used to declare someone demis or death. In this research the researcher found 5 utterances that were the types of declaration of illocutionary act that is demising. The researcher found in $8^{\text {th }}, 9^{\text {th }}, 10^{\text {th }}$, and $12^{\text {th }}$ episode of the drama.

\section{Table 4 Demising declaration}

\begin{tabular}{|c|c|c|l|}
\hline No. & $\begin{array}{c}\text { Code } \\
\text { (Episode) }\end{array}$ & Time & \multicolumn{1}{c|}{ Utterance } \\
\hline 1. & 8 & 00.00 .11 & $\begin{array}{l}\text { Reporter: } \\
\text { "Around 11.00 last night, at a chicken restaurant Myeong } \\
\text { Woldong, Seongmo city, a fire broke out from an known } \\
\text { cause. The fire, after partially burning the restaurant, causing } \\
\text { property damage which the fire department estimated at 5,4 } \\
\text { million Won, was extinguished in 15 minute. In the accident, } \\
\text { the 52 years old owner, Ms.Eo Choon Shim died." }\end{array}$ \\
\hline 2. & 9 & $00: 41: 18$ & $\begin{array}{l}\text { Reporter: "Last night, around 9, at a fishing area in Yoen Ju, } \\
\text { a left hand severed from a corpse was found so the police } \\
\text { have started their investigation. Looking at the fingerprints } \\
\text { on the hand, the owner of the hand is Mr. Min, who is on the } \\
\text { wanted list." }\end{array}$ \\
\hline 3. & 12 & $00: 50: 41$ & $\begin{array}{l}\text { Directur Yang: "Prosecutor, something big happened. The } \\
\text { fruit store owner, Moon Seong Nam, who was called in for } \\
\text { witness, in an accident yesterday night. she was dead." }\end{array}$ \\
\hline Total: & \multicolumn{3}{|c|}{} \\
\hline
\end{tabular}

\section{Naming}

Naming is expression used to declare something name or naming something. In this research the researcher found 7 utterances that be one of the types of declaration illocutionary acts that is 
naming. The researcher found in $9^{\text {th }}, 10^{\text {th }}$, and $13^{\text {th }}$ episode of the drama presented in the table below:

Table 5 Naming declaration

\begin{tabular}{|r|c|c|l|}
\hline No. & $\begin{array}{c}\text { Code } \\
\text { (Episode) }\end{array}$ & Time & \multicolumn{1}{|c|}{ Utterance } \\
\hline 1. & 9 & $00: 21: 31$ & $\begin{array}{l}\text { Police 2: “I think its smoke bomb. Like the ones used to kill the } \\
\text { cockroaches." }\end{array}$ \\
\hline 2. & 10 & $00: 05: 54$ & $\begin{array}{l}\text { Reporter: "Dismembered left hand found at fishery. Body seems } \\
\text { to have been mutilated following the murder. Murder suspect of } \\
\text { the "left hand" case_arrested. Took shelter for a year in a } \\
\text { farming village." }\end{array}$ \\
\hline 3. & 10 & $00: 25: 10$ & $\begin{array}{l}\text { Lawyer Cha Gwang Woo: "About Park Soo Ha's case...how } \\
\text { about we make this into a case of Trial By Jury?" }\end{array}$ \\
\hline 4. & 10 & $01: 04: 16$ & $\begin{array}{l}\text { Lawyer Shin: 'It's going to the same way as Hwang Dal Jong's } \\
\text { case went 26 years ago. How despicable. Even the case's } \\
\text { nickname is the same. The left-hand murdered case." }\end{array}$ \\
\hline 5. & 13 & $00: 13: 34$ & $\begin{array}{l}\text { Lawyer Jang: "The case is attempted murder for stabbing an } \\
\text { assaultive husband." }\end{array}$ \\
\hline 6. & 13 & $00: 13: 51$ & $\begin{array}{l}\text { Park Soo Ha : Hey, what's with "bloody crap" while eating. } \\
\text { "bloody crap". You could just say that you're going }\end{array}$ \\
\hline 7. & 13 & $00: 42: 18$ & \begin{tabular}{l} 
Park Soo Ha : Is it dog food again? \\
\hline Total
\end{tabular} \\
\hline
\end{tabular}

\section{Appointing}

Appointing is expression used to declare someone accepted for a job. The researcher in this research found 8 utterances of declaration illocutionary act in episode $8^{\text {th }}, 10^{\text {th }}, 12^{\text {th }}$, and $13^{\text {th }}$. Those utterances were categorized into one of the types of declaration illocutionary act that was appointing. The data of appointing utterances presented in the table below:

Table 6 Appointing Declaration

\begin{tabular}{|c|c|c|l|}
\hline No. & $\begin{array}{c}\text { Code } \\
\text { (Episode) }\end{array}$ & Time & \multicolumn{1}{c|}{ Utterance } \\
\hline 1. & 8 & 00.01 .04 & $\begin{array}{l}\text { Judge 2: "Has the suspect been charged with arson?" } \\
\text { Judge 1: "Yes, did you know that the case has been assigned to } \\
\text { our court?" } \\
\text { The Judges 1: "Exactly, why, of all places, does it have to be } \\
\text { us? The incident was in Seongmo city." } \\
\text { The judges 3: "It seems this is jurisdiction of the defendant's } \\
\text { residence and the requested a transfer." }\end{array}$ \\
\hline
\end{tabular}




\begin{tabular}{|c|c|c|c|}
\hline 2. & 8 & 00.13 .54 & $\begin{array}{l}\text { The Judge } 1 \\
\text { "We don't know yet if he killed her mother or not! We will } \\
\text { know that only after the trial. I fully understand you're in a } \\
\text { difficult position. However, this is not a matter which you have } \\
\text { the liberty of choice. For this kind of situation, public defenders } \\
\text { are changed with exclusive responsibility. And you're that } \\
\text { exclusive public defender, lawyer Cha." } \\
\text { Lawyer Cha: "Then, please change to lawyer Shin. I will } \\
\text { personally request it of Lawyer Shin." } \\
\text { The Judges 1: "That would be difficult too". }\end{array}$ \\
\hline 3. & 8 & 00.14 .22 & $\begin{array}{l}\text { Lawyer Cha: "why?" } \\
\text { The Judges 1: "Min Joong Gook requested us to assign you as } \\
\text { his lawyer" }\end{array}$ \\
\hline 4. & 10 & 00:08:24 & $\begin{array}{l}\text { Lawyer Jang Hye Sung: "A public defender was requested. I'm } \\
\text { Park Soo Ha's public defender. So, I'm also going to the } \\
\text { inspection of the scene." }\end{array}$ \\
\hline 5. & 10 & $00: 13: 44$ & $\begin{array}{l}\text { Lawyer Jang Hye Sung: "Suddenly why are you being like this? } \\
\text { You're the prosecutor of this case." }\end{array}$ \\
\hline 6. & 10 & $00: 43: 42$ & $\begin{array}{l}\text { Prosecutor Seo Do Yeon: "I'm the public prosecutor for this } \\
\text { case, Prosecutor Seo Do Yeon. I stand here today to assist you } \\
\text { to make judgment. In order to help you understand this case, } \\
\text { I've prepare a presentation. (showing unusual presentation)" }\end{array}$ \\
\hline 7. & 10 & $00: 31: 25$ & $\begin{array}{l}\text { Lawyer Cha Gwang Woo: "Yes, I was also assigned to Park } \\
\text { Soo Ha's case. Since I don't have an office, I'm going to borrow } \\
\text { one here." }\end{array}$ \\
\hline 8. & 12 & 00:09:02 & $\begin{array}{l}\text { Lawyer Cha: 'I'll do it. Park Soo Ha's lawyer. I said I'll be his } \\
\text { lawyer.". }\end{array}$ \\
\hline 9. & 13 & $00: 28: 19$ & $\begin{array}{l}\text { Prosecutor Cho: "Prosecutor Seo, Hwang Dal Choong's case } \\
\text { has been passed down to me" }\end{array}$ \\
\hline 10. & 13 & $00: 36: 14$ & $\begin{array}{l}\text { Jang Hye Sung: "So, you want Hwang Dal Choong's case as a } \\
\text { jury trial with me?" }\end{array}$ \\
\hline Total: & & & 10 \\
\hline
\end{tabular}

\section{Sentencing}

Sentencing is an utterance that used to state that someone is to have a certain punishment. In this drama from chapter 8 to 13 the researcher found 17 sentencing declaration and 2 others from chapter 16 and 18. Those data of sentencing utterances presented in table below:

Table 7 Sentencing Declaration

\begin{tabular}{|c|c|c|l|}
\hline No. & $\begin{array}{c}\text { Code } \\
\text { (Episode) }\end{array}$ & Time & Utterance \\
\hline 1. & 8 & 00.23 .44 & Prosecutor Seo Do Yeon: \\
\hline
\end{tabular}




\begin{tabular}{|c|c|c|c|}
\hline & & & $\begin{array}{l}\text { "Therefore, defendant Min Joon Gook is charged, under } \\
\text { penal code article } 250 \text { pursuant to section 64, with Arson and } \\
\text { Homicide by Arson." }\end{array}$ \\
\hline 2. & 8 & 00.38 .38 & $\begin{array}{l}\text { Lawyer Shin :" So, you're going out? As a witness on the Min } \\
\text { Joon Gook case? "Tiffany" } \\
\text { Hwang Dal Joong :"Yes, at the next court session, I'm going } \\
\text { out as a witness." (00.38.44) } \\
\text { Lawyer Shin :" Why are you going out as a witness? For the } \\
\text { prosecution's side? Didn't you said that Min Joon Gook was } \\
\text { a good person?" }\end{array}$ \\
\hline 3. & 9 & 00:09:19 & $\begin{array}{l}\text { The judges 1: } \\
\text { "Defendant Min Joong kook was indicted for murder as } \\
\text { follows : on June,9,2012in Myeongwondong, Sangmoo city } \\
\text { at Eo Choon Shim's chicken restaurant, he struck the victim } \\
\text { with a blunt instrument rendering her unconsciousness. After } \\
\text { which, he started the fire to camouflage it as an accident. } \\
\text { Therefore, he would have acted differently if he had really } \\
\text { wanted to murder. So, there is enough doubt to mitigate the } \\
\text { charges against the defendant. According to the law, if there } \\
\text { is reasonable doubt of the guilt, then the court must find the } \\
\text { defendant innocent. The fundamental principle in criminal } \\
\text { procedure being that decision must be made in favor of the } \\
\text { defendant. Therefore, per Law of Court, section 325, the } \\
\text { defendant is acquitted." }\end{array}$ \\
\hline 4. & 9 & $00: 38: 07$ & $\begin{array}{l}\text { Lawyer Jang Hye Sung: } \\
\text { "Min Joong Kook has been charged for attempted murderer } \\
\text { and retaliation." }\end{array}$ \\
\hline 5. & 9 & $00: 42: 08$ & $\begin{array}{l}\text { Lawyer Jang: "I'm Jang Hye Sung, a public defender. I'm } \\
\text { Park Soo Ha's guardian." } \\
\text { Police: "You should have been a proper guardian. He killed a } \\
\text { person." If we have that much evidence, it doesn't make sense } \\
\text { that the criminal is Park Soo Ha? (00:42:26) }\end{array}$ \\
\hline 6. & 10 & $00: 01: 24$ & $\begin{array}{l}\text { Police: "I can't. He confessed that he killed him with his own } \\
\text { hands. How can I let go a criminal? He might be pretending } \\
\text { to have lost his memory. We'll do this according to the law. } \\
\text { We'll file for an arrest warrant, and when it is issued, he will } \\
\text { be detained unconditionally." } \\
\text { ( 00:01:50) }\end{array}$ \\
\hline 7. & 10 & $00: 11: 19$ & $\begin{array}{l}\text { Lawyer Jang Hye Sung: "Don't take of the masked, please! } \\
\text { He's still in the position of an accused." }\end{array}$ \\
\hline 8. & 10 & $00: 44: 18$ & $\begin{array}{l}\text { Prosecutor Seo Do Yeon: "In this case the victim, Min Joon } \\
\text { Kook, murdered the father's defendant Park Soo Ha } 11 \text { years } \\
\text { ago. Even after Min Joon Kook was released from jail, he } \\
\text { stalked the defendant and last year, he injured the defendant. } \\
\text { The defendant, bearing a grudge against the victim, around at }\end{array}$ \\
\hline
\end{tabular}




\begin{tabular}{|c|c|c|c|}
\hline & & & $\begin{array}{l}\text { 23:00 hours on Jully, } 22^{\text {nd }}, 2012 \text {, met the victim at Big Fish } \\
\text { Fishery in Yeon Joo City and killed him. And, he } \\
\text { dismembered the body, it is believed that he hid the body parts } \\
\text { in the river." }\end{array}$ \\
\hline 9. & 10 & $00: 45: 24$ & $\begin{array}{l}\text { Prosecutor Seo Do Yeon: "In accordance with article } 250 \text { and } \\
161 \text { of the Criminal Law, the prosecution is charging the } \\
\text { murder, destruction and mutilation of the corpse, and } \\
\text { concealment of the body." }\end{array}$ \\
\hline 10. & 10 & $01: 04: 45$ & $\begin{array}{l}\text { Lawyer Cha: "Yes, there is one suspect that matches up with } \\
\text { all the evidence. Min Joon Kook." }\end{array}$ \\
\hline 11. & 11 & $00: 06: 36$ & $\begin{array}{l}\text { The judge 1: "Finally, in regard to this case's charge, we } \\
\text { cannot view that there is no evidence beyond reasonable } \\
\text { doubt, and in this situation, when doubtful, following the } \\
\text { great principle of criminals suits that defendant's there's no } \\
\text { choice but judge so. As such, in accordance with latter part } \\
\text { of the criminal code } 325, \text { the defendant... is not guilty." }\end{array}$ \\
\hline 12. & 12 & $00: 12: 24$ & $\begin{array}{l}\text { Hwang Dal Jong: "Thank you. If it wasn't for you, Lawyer } \\
\text { Shin, I wouldn't even have anyone to sign me out." }\end{array}$ \\
\hline 13. & 12 & 00:08:17 & $\begin{array}{l}\text { Prosecutor Seo: 'Because we weren't looking for him. As of } \\
\text { now, we have to start looking for him. Director Yang. Send } \\
\text { Moon Suk Nam a letter summoning her as a witness" }\end{array}$ \\
\hline 14. & 12 & $00: 51: 43$ & $\begin{array}{l}\text { Prosecutor Seo: "Starting from now, we are stating that Min } \\
\text { Joon Kook is alive. Get Min Joon Kook on the wanted list." }\end{array}$ \\
\hline 15. & 13 & $00: 01: 41$ & $\begin{array}{l}\text { Lawyer Jang Hye Sung: "Hey, you stupid. That's a later } \\
\text { problem. Seo Do Yeon said she won't look into your case any } \\
\text { further. So, you are not a defendant," }\end{array}$ \\
\hline 16. & 13 & 00:11:01 & $\begin{array}{l}\text { Detective Kang : "What's wrong with Hwang Dal } \\
\text { Choong? As soon as he was released he stabbed a person, and } \\
\text { now he's come looking for you" }\end{array}$ \\
\hline 17. & 13 & $00: 23: 32$ & $\begin{array}{l}\text { Prosecutor Seo: "Criminal Code Article } 250 \text { Paragraph } 1 \text { is } \\
\text { applicable. Under the provisions of Article 250, the } \\
\text { Defendant is charged with attempted murder." }\end{array}$ \\
\hline 18. & 16 & 00:03:06 & $\begin{array}{l}\text { Judge 1: "we will start the verdict for the case } 20131354 \\
\text { Hwang Dal Joong. The result of the jury verdict deviates from } \\
\text { existing jurisprudence and our opinion, it cannot be said that } \\
\text { it is completely incorrect. As such, in accordance with the } \\
\text { Criminal Law 328-1-1, the prosecution is dismissed." }\end{array}$ \\
\hline 19. & 18 & $00: 56: 55$ & $\begin{array}{l}\text { Judge 1: "all the crimes he has committed was for revenge, to } \\
\text { cover up those crimes, he has killed innocent people. He cover } \\
\text { it up by making it look like an accident with his extremely } \\
\text { cruel ways. However, the victim Doctor Woo forged the } \\
\text { documents making the reason the defendant's wife die. The } \\
\text { defendant Life sentence" }\end{array}$ \\
\hline Total: & & & 19 \\
\hline
\end{tabular}




\section{CONCLUSION}

After analyzing the data of declaration of illocutionary act, the researcher accomplished to the conclusion as follows:

a. In the Korean-English drama "I Hear Your Voice", in episode 8 to 13 found 40 utterances of declaration of illocutionary act. Those utterances classified into five categories that are resigning, demising, naming, appointing and sentencing. From 40 declaration utterances were found there are 2 utterances of resigning it was $5 \%$ from $100 \%$ total, $12,5 \%$ consist of 5 utterances of demising, 17,5\% consist 7 utterances of naming, $20 \%$ consist of 8 utterances of appointing and $45 \%$ consist of 18 utterances of sentencing.

b. The result of this research can be implicated on the English Language Teaching. The teachers can use this research as an authentic material to teach Pragmatic especially about Speech Acts. In addition, the result of this research able to used to teach about the expressions. Those are expression of resigning, demising, naming, appointing, and sentencing.

After analyzing the data and discussing the result, the researcher give some suggestions as follows:

a. English Teacher

The researcher hopes the English teacher can use this study as the authentic material to teach speech act.

b. English Department Students

The researcher hope this research could be one of references in studying speech act especially to give more understanding about declaration illocutionary act as one of the part of illocutionary categories by Searle.

c. The future researcher

This research could be one of the references in studying speech acts and for the other researcher, the researcher advice to use the title or topic, but which has not been conducted yet, such as types of locutionary acts, types of perlocutionary acts, or other types of illocutionary acts. 


\section{REFERENCES}

Anisawati,Eka (2012). Speech Act Analysis in Opera Van Java (OVJ) Dialogue in Episode "Bima Kawin”. STAIN Salatiga. Graduating Paper.

Arikunto, Suharsini. 2010. Prosedur Penelitian “Suatu Pendekatan Praktis”. Jakarta: Rineka Cipta.

Austin,J.L (1967). How to Do Things with Words. Cambridge: Harvard University Press.

Cahyono, Bambang Yudi. 1995. Kristal- Kristal Ilmu Bahasa. Surabaya: Airlangga University Press.

Handayani, Jati (2012). The Study of Speech Acts the "Body of Lies” the Movie. Salatiga: STAIN Salatiga. Graduating Paper.

Heitler, David (2005). Teaching with Authentic Materials. Longman: Pearson Education.

Kasiran, Moh (2010). Metodologi Penelitian Kualitatif-Kuantitatif. Malang: UIN -Maliki Press.

L. Mey,Jacob (1998). Concise Encyclopedia of Pragmatics. UK: Elsever Science Ltd.

L.Mey,Jacob (1993). Pragmatics. USA: Blackwell

L.Mey,Jacob (1994). Pragmatics an Introduction. London: Basil Blackwell

Leech,Geoffrey (1991). Principles of Pragmatics. New York: Longman Inc.

Moleong, Lexy. J (2002). Metodologi Penelitian Kualitatif. Bandung: PT Remaja Rosdakarya.

Parker, Frank (1986). Linguistics For Non-Linguistics. London: Taylor \& Francis Ltd.

Schiffrin, Deborah. 1994. Approaches to Discourse. USA: Blackwell Published.

Searle, John R. 1969. Speech Act: An Essay in the Philosophy of Language. London: Cambridge University Press.

Sukardi. 2008. Metodologi Penelitian Pendidikan. Jakarta: PT Bumi Aksara.

Tamo, Daniela (2009). The Use of Authentic Materials in Classrooms. LCPJ 2009. Vol 2. No. 1. Retrieved Monday, November 18, 2013, 12:50:36 PM at http://www.lcpj.pro

Yule, George. 1996. Pragmatics. New York: Oxford University Press. 